\title{
Magdalena Gojny*
}

\section{KIERUNKI ROZWOJU ZARZĄDZANIA JEDNOSTKĄSAMORZĄDUTERYTORIALNEGO}

Zarys treś ci: Zarządzanie to ,zorganizowany proces oddziaływania kierującego na zasoby organizacji za pomocą określonych środków, form i metod, zapewniający sprawne osiąganie stojących przed organizacją legalnie ustalonych celów" [Zawadziak, 2014, s. 52]. Na przestrzeni lat, zmieniających się warunków otoczenia, oczekiwań obywateli, rozwoju technologii, obserwuje się proces ewolucji metod zarządzania publicznego od autokratycznego po menedżeryzm. Niniejsze opracowanie prezentuje koncepcje teoretyczne zarządzania publicznego, które ze względu na wąskie ramy zostało ograniczone do krótkiego zarysu.

Słow a kluczowe: jednostka samorządu terytorialnego, zarządzanie publiczne Klasyfikacja JEL: L31

\section{WSTĘP}

Artykuł 15 ust. 1 Konstytucji Rzeczypospolitej Polskiej z dnia 2 kwietnia 1997 r. stanowi, że „ustrój terytorialny Rzeczypospolitej Polskiej zapewnia decentralizację władzy publicznej". Decentralizacja oznacza wykonywanie zadań publicznych poprzez aparat administracyjny, zbudowany przez różne podmioty, charakteryzujący się niejednolitą oraz wewnętrznie zróżnicowaną strukturą organizacyjną [Bukowski Z., Jędrzejewski T., Rączka P., 2011, s. 19-27]. Struktura samorządu terytorialnego w Polsce

Adres do korespondencji: Magdalena Gojny, Politechnika Gdańska, Wydział Zarządzania i Ekonomii, Katedra Analizy Ekonomicznej i Finansów, Traugutta 79, 80-233 Gdańsk, e-mail: magda.rafal@gmail.com. 
wykształciła się w efekcie długiego oraz skomplikowanego procesu, na który wpływ wywierały zmiany polityczne i gospodarcze [Wójtowicz W., 2002, s. 87]. Samorząd terytorialny jest powstałym z mocy prawa i wyodrębnionym w strukturze państwa związkiem lokalnego społeczeństwa, powołanym do samodzielnego wykonywania zadań administracji państwowej i wyposażonym w materialne środki umożliwiające ich realizację [Podstawka M., 2001, s. 152]. Ustawa z dnia 8 marca 1990 r. o samorządzie terytorialnym [Dz. U. $1990 \mathrm{nr}$ 16, poz. 95] utworzyła samorząd terytorialny na szczeblu gminnym. Dalsza decentralizacja sektora publicznego nastąpiła w drodze tzw. reformy ustrojowej, którą przeprowadzono w 1998 roku. Jej efektem było utworzenie samorządu terytorialnego na szczeblu powiatowym [Dz. U. 1998 nr 91, poz. 578] oraz wojewódzkim [Dz. U. $1998 \mathrm{nr}$ 91, poz. 576].

Celem wyodrębnienia ze struktur państwowych samorządu terytorialnego jest przekazanie odpowiedzialności za realizację podstawowych zadań państwa wobec jego mieszkańców. Do zadań tych należą m.in.: świadczenie podstawowych usług publicznych, troska o zapewnienie obywatelom pomocy oraz ochrony w trudnych sytuacjach życiowych, jak również kreowanie warunków sprzyjających rozwojowi samorządności gminnej i lokalnej gospodarki [Wankiewicz B., 2009, s. 9]. Jak przewidywał P.F. Drucker: „,...] Wszystko wskazuje więc na to, że w XXI wieku sektor wzrostu w krajach rozwiniętych nie będzie związany ze sferą biznesu. Najprawdopodobniej będzie nim nie nastawiony na zysk sektor publiczny, w którym obecnie niezwykle potrzebne jest przeprowadzenie systematycznych, konkretnych działań, będących praktycznym zastosowaniem zasad zarządzania, co w efekcie może przynieść w ciągu krótkiego okresu bardzo dobre rezultaty" [Drucker P.F., 2000, s. 8-9].

We współczesnym, globalnym, dynamicznie rozwijającym się świecie, gdzie jedyną constans jest zmiana, jednostki samorządu terytorialnego (JST) ,[...] mają niewielki wybór: żeby przetrwać i prosperować, muszą sprzyjać pragmatyzmowi i umieć radzić sobie z trudnościami. Muszą też współpracować, wspierać tworzenie sieci, z życzliwością traktować kreatywność i innowacje" [Barber B.R., 2014, s. 29]. Zarządzanie publiczne w kontekście niniejszego artykułu „oznacza zespół działań podejmowanych w celu wywołania pożądanego przebiegu procesów i zjawisk (działalności gospodarczej) w obrębie samorządu terytorialnego" [Wojciechowski E., 2012, s. 15]. Sprawne oraz efektywne zarządzanie ma bezpośredni wpływ na budowanie dobrobytu społecznego, dlatego też zarządzanie publiczne jest obecnie jedną $\mathrm{z}$ najbardziej dynamicznie rozwijających się $\mathrm{w}$ Polsce 
subdyscyplin nauk o zarządzaniu ${ }^{1}$. Celem niniejszego opracowania jest próba usystematyzowania zmian w metodach zarządzania publicznego oraz ocena rozwoju tejże dyscypliny w praktyce funkcjonowania JST. Podstawą rozważań są źródła literaturowe dotyczącej omawianej problematyki.

\section{ZARZĄDZANIE ADMINISTRACYJNE}

Jednym z głównych przedstawicieli zarządzania administracyjnego jest niemiecki socjolog Max Weber ${ }^{2}$, który znany jest głównie jako twórca modelu idealnej biurokracji ${ }^{3}$. Największe zainteresowania paradygmatem biurokratycznym obejmuje okres od lat 20. do późnych lat 70. XX w., co ma związek z radykalnymi zmianami społecznymi i gospodarczymi, które wystąpiły po II wojnie światowej [Batko R., 2013, s. 51].

Biurokracja to „uniwersalny model struktury organizacyjnej oparty na zalegalizowanym systemie władzy formalnej" [Griffin R.W., 1999, s. 362]. Weberowski model biurokracji charakteryzuje się niezależnością od otoczenia, zależnością od silnego ośrodka władzy, stabilnymi stosunkami władzy, rutynową pracą, którą ściśle określają procedury oraz znikomą zdolnością reagowania na niepewność [Kowalczyk L., 2008, s. 7-8]. Organizacja zarządzana zgodnie $\mathrm{z}$ jej zasadami przypomina organizację mechanistyczną, która najczęściej znajduje zastosowanie w jednostkach funkcjonujących w stabilnym otoczeniu [Griffin R.W., 1999, s. 362].

1 Od 1 stycznia 2016 r. obowiązują przepisy ustawy z dnia 25 czerwca 2015 r. o zmianie ustawy o samorządzie gminnym oraz niektórych innych ustaw (Dz. U. 2015 poz. 1045), której celem jest umożliwienie wspólnej obsługi administracyjnej, finansowej oraz organizacyjnej jednostek należących do sektora finansów publicznych (tworzenie tzw. centrów usług wspólnych), jak również stworzenie podstawy prawnej do tworzenia związków powiatowo-gminnych, co ma wpłynąć na lepszą współpracę pomiędzy wymienionymi jednostkami samorządu terytorialnego [http://www.portalsamorzadowy.pl/prawo-i-finanse/ustawao-samorzadzie-gminnym-podpisana-przez-prezydenta,72124.html].

2 Inni twórcy nurtu zarządzania administracyjnego to: H. Fayol, L. Urwick, Ch. Barnard.

3 Po raz pierwszy model idealnej biurokracji został przedstawiony w $1922 \mathrm{r}$. w dziele Wirtschaft und Gesellschaft. Max Weber, tworząc organizację biurokratyczną, wzorował się na modelu funkcjonowania wojska za czasów króla Prus Fryderyka Wielkiego, którego wojsko działało jak mechaniczne zabawki, automaty [Zawadziak T., 2014, s. 56; Hausner J., 2008, s. 13]. 
Max Weber zaprezentował pięć podstawowych cech idealnej biurokracji - patrz tabela 1 [Griffin R.W., 1999, s. 363]. Uważał, że zastosowanie tego paradygmatu będzie miało pozytywne konsekwencje ogólnospołeczne wynikające z:

- zapewnienia możliwie szerokiej bazy rekrutacji kandydatów według kryteriów kompetencji zawodowej;

- dążenia do maksymalnego wydłużenia okresu zdobywania kwalifikacji zawodowych, co doprowadzi do rządów plutokratycznych;

- dominacji ducha formalistycznej bezosobowości;

- ustanowienia norm związanych z poczuciem obowiązku, które nie będą uwarunkowane względami osobistymi [Hausner J., 2008, s. 15].

Tabela 1. Podstawowe cechy idealnej biurokracji według M. Webera

\begin{tabular}{|l|l|}
\hline \multicolumn{1}{|c|}{ CECHA } & \multicolumn{1}{|c|}{ CHARAKTERYSTYKA } \\
\hline Kompetencja & $\begin{array}{l}\text { Wyraźny podział pracy oraz obsadzenie każdego stanowiska przez } \\
\text { eksperta }\end{array}$ \\
\hline Przewidywalność & $\begin{array}{l}\text { Stworzenie spójnego zestawu zasad umożliwiającego jednolite } \\
\text { wykonywanie zadań }\end{array}$ \\
\hline Mechaniczność & $\begin{array}{l}\text { Ustalona hierarchia stanowisk dla urzędów, która tworzy linię } \\
\text { podporządkowania od góry do dołu organizacji }\end{array}$ \\
\hline Racjonalność & $\begin{array}{l}\text { Zarządzanie organizacją w sposób bezosobowy oraz utrzymywanie } \\
\text { odpowiedniego dystansu pomiędzy pracownika szczebla kierowni- } \\
\text { czego z podwładnymi }\end{array}$ \\
\hline Obiektywizm & $\begin{array}{l}\text { Zatrudnianie pracowników oraz ich awansowanie powinno opierać } \\
\text { się na technicznej wiedzy fachowej, natomiast pracownicy powinni } \\
\text { być chronienie przed arbitralnym zwolnieniem }\end{array}$ \\
\hline
\end{tabular}

Źródło: opracowanie własne na podstawie Griffin R.W., Podstawy zarzadzania organizacjami, Wydawnictwo Naukowe PWN, Warszawa 1999, s. 363.

Praktyczne zastosowanie omawianego paradygmatu nie gwarantuje merytokracji, a wraz z rozrastającymi się strukturami administracyjnymi pojawiają się takie dysfunkcje, jak nepotyzm, klientelizm, korupcja. O słabości modelu stanowią także rozrastające się ciągle przepisy i reguły, nieprecyzyjność języka, podporządkowanie interesom pracownika oraz skoncentrowanie na procedurze, a nie wyniku działania administracyjnego [Hausner J, 2008, s. 16].

Współcześnie model M. Webera jest wyłącznie teoretyczny, gdyż nie ma odwzorowania w czystej postaci [Griffin R.W., 1999, s. 77], co nie zmie- 
nia faktu, że w JST nadal dostrzega się pewne jego cechy. Przez współczesnych obywateli urzędnik nadal postrzegany jest jako osoba odgrywająca rolę strażnika publicznego uosabiającego państwo. JST odznaczają się hierarchicznym podporządkowaniem ograniczonym do danej struktury oraz zespoleniem, polegającym na skoncentrowaniu w jednym urzędzie oraz pod jednym zwierzchnikiem. Kolejną cechą jest formalizacja działań przejawiająca się wykonywaniem władczych kompetencji wobec mieszkańców gminy, np. na podstawie przepisów o postępowaniu administracyjnym, prawa lokalnego, postępowania egzekucyjnego, a także wobec pracowników JST - np. regulamin pracy. Sojusznikiem modelu Webera we współczesnych JST może się okazać tzw. e-administracja [Kulesza M., Sześciło D., 2013, s. 52-56].

\section{NOWE ZARZĄDZANIE PUBLICZNE (NPM)}

Istotą NPM jest ,traktowanie administracji publicznej jako osobnej kategorii w obrębie struktury i mechanizmów zarządzania publicznego; w związku z kryzysem finansów publicznych skupiono się na racjonalizacji wydatków publicznych [...] uelastycznienie struktur i statusu pracowników, analizę i kwantyfikację celów, kosztów i efektów oraz prywatyzację w znaczeniu własnościowym i funkcjonalnym [...]" [Hausner J., 2008, s. 24]. Koncepcja NPM powstała w latach 80 . XX w., a jej źródła tkwią w teorii ekonomii instytucjonalnej oraz wyboru publicznego. Reformy NPM opierają się na mechanizmach oraz instrumentach reprezentatywnych dla jednostek sektora prywatnego [Kożuch B., 2015, s. 34]. Ch. Hood określił ten paradygmat jako podejście oparte na następujących postulatach:

- wprowadzenie do zarządzania sektorem publicznym technik menedżerskich;

- jasno określone standardy i mierniki efektywności działania;

- zwiększenie nacisku na monitorowanie oraz ocenę rezultatów działania;

- tworzenie małych, wyspecjalizowanych, elastycznie kształtowanych departamentów, zespołów zadaniowych;

- wprowadzenie konkurencji;

- adaptacja do sektora publicznego metod zarządzania wykorzystywanych w biznesie;

- oszczędne i zdyscyplinowane korzystanie z zasobów sektora publicznego [Kulesza M., Sześciło D., 2013, s. 66]. 
Podstawowe cechy NPM prezentuje tabela 2.

Realizacja NPM przez JST przybiera formę: partnerstwa publiczno-prywatnego, prywatyzacji, dezagregacji, większej autonomii menedżerów, planowania strategicznego, business process reeingineering, kontroli kosztów i efektywności, budżetowania wyników, kontraktowania, zarządzania wynikami, eksperymentowania, zarządzania jakością, zarządzania przez cele, opłat za usługi [Frączkiewicz-Wronka A., 2008, s. 23].

Tabela 2. Podstawowe cechy NPM według D.F. Kettla

\begin{tabular}{|l|l|}
\hline \multicolumn{1}{|c|}{ CECHA } & \multicolumn{1}{c|}{ CHARAKTERYSTYKA } \\
\hline Wydajność & $\begin{array}{l}\text { Maksymalizacja usług wobec mieszkańców z wykorzystaniem } \\
\text { takiej samej lub mniejszej ilości środków publicznych }\end{array}$ \\
\hline Urynkowienie & $\begin{array}{l}\text { Prywatyzacja przedsiębiorstw publicznych, odpowiedzialność } \\
\text { za realizację usług wobec mieszkańców przez podmioty prywatne }\end{array}$ \\
\hline Orientacja na usługi & $\begin{array}{l}\text { Poprawa jakości świadczonych usług, realny wybór obywateli } \\
\text { modelu świadczenia usług na ich rzecz }\end{array}$ \\
\hline Decentralizacja & $\begin{array}{l}\text { Wiéksza odpowiedzialność i samodzielność decyzyjna urzędni- } \\
\text { ków JST }\end{array}$ \\
\hline Polityka publiczna & $\begin{array}{l}\text { Umożliwienie administracji większej zdolności do określania } \\
\text { zakresu usług publicznych }\end{array}$ \\
\hline $\begin{array}{l}\text { Odpowiedzialność za } \\
\text { wyniki }\end{array}$ & $\begin{array}{l}\text { Odpowiedzialność głównie za jakość usług, a nie ich dostarcza- } \\
\text { nie zgodne z obowiązującymi procedurami }\end{array}$ \\
\hline
\end{tabular}

Źródło: opracowanie własne na podstawie Polityka administracyjna i zarządzanie publiczne, Kulesza M., Sześciło D., Wolters Kluwer Polska SA, Warszawa 2013, s. 62-64.

Wśród wad NPM należy wymienić dekoncentrację na efektywności JST z perspektywy zdolności do zaspokajania społecznych potrzeb oraz brak wytycznych dotyczących oceny organizacji, a także pominięcie wpływu polityki na podejmowane przez władzę publiczną decyzje [Supernat J., dostęp 23.01.2016].

W praktyce koncepcja NPM w JST wiąże się z zarządzaniem strategicznym. W latach 90. XX w. z pomocą realizacji programów finansowanych przez Agencję Rozwoju Międzynarodowego USAID i brytyjskiego funduszu Know-How Fund do JST wprowadzony został budżet zadaniowy 
(wynikowy) ${ }^{4}$. JST, mając na celu lepsze dostosowanie działań do wymagań petentów i poprawę organizacji pracy, zaczęly wdrażać system zarządzania jakością oparty na wymaganiach normy ISO 9001:2000 [http://samorzad. infor.pl/temat_dnia/387395,System-zarzadzania-jakoscia-w-jednostkach-s amorzadu-terytorialnego.html]. Wśród samorządów bardzo rozpowszechniła się forma partnerstwa publiczno-prywatnego, która sprzyja poszukiwaniom efektywnych modeli gospodarowania środkami publicznymi.

\section{PUBLIC GOVERNANCE (PG)}

$\mathrm{PG}^{5}$ jest koncepcją zarządzania, w której JST ,jest ważnym elementem społeczeństwa [...] i pozostaje $\mathrm{w}$ interakcji z członkami [...] społeczeństwa obywatelskiego [...] poprzez odpowiednie procedury partycypacyjne i konsultacyjne z interesariuszami" [Hausner J., 2008, s. 24]. PG wywodzi się z socjologii i obejmuje takie koncepcje, jak: Governance, New Public Governance, Good Governance oraz New Public Leadership - patrz tabela 3 [Kulesza M., Sześciło D., 2013, s. 116].

Cechy charakterystyczne dla zarządzania zgodnego z PG to: neutralność, wysokie kompetencje urzędnicze, odpowiedzialność, budowanie struktur gwarantujących funkcjonowanie organizacji zgodnie z zasadami prawa. Istotną rolę odgrywają w nim nowoczesne technologie cyfrowe oraz komunikacyjne [Hausner J., 2008, s. 24; Kożuch B., 2015, s. 33].

Porównując metodę NPM i PG, trudno nie zauważyć podobieństw, takich jak:

- osłabienie roli liderów politycznych, którzy są wypierani przez mieszkańców;

- zanikanie różnic i rozdziału występujących między sektorem publicznym i prywatnym;

- wzrost znaczenia mechanizmów konkurencyjnych w zarządzaniu JST;

- koncentracja na osiągnięte wyniki procesów zarządzania;

- koncentracja działań JST na „sterowaniu niż wiosłowaniu”.

4 W 1994 r. budżet zadaniowy wprowadził Kraków, a następnie Lublin, Szczecin i Poznań [http://capepoint.pl/budzet_zadaniowy_w_samorzadach].

5 Pojęcie to określane jest również jako corporate governance, civic governance. 
Tabela 3. Charakterystyka koncepcji Public Governance

\begin{tabular}{|l|l|}
\hline \multicolumn{1}{|c|}{ KONCEPCJA } & \multicolumn{1}{c|}{ CHARAKTERYSTYKA } \\
\hline Governance & $\begin{array}{l}\text { Tzw. ,miękka” teoria zarządzania publicznego, polegająca na } \\
\text { niewymuszonym współdziałaniu samodzielnych podmiotów, które } \\
\text { współpracują ze sobą w oparciu o zaufanie i współodpowiedzial- } \\
\text { ność }\end{array}$ \\
\hline $\begin{array}{l}\text { New Public Gover- } \\
\text { nance }\end{array}$ & $\begin{array}{l}\text { Jego istotą jest postrzeganie roli podmiotów pozarządowych } \\
\text { w zarządzaniu publicznym, jako współuczestników procesów } \\
\text { zarządzania, których relacje kontraktowe opierają się na zaufaniu } \\
\text { i współdziałaniu }\end{array}$ \\
\hline Good Governance & $\begin{array}{l}\text { Uczestnictwo wszystkich obywateli w procesach decyzyjnych; } \\
\text { gwarancje ochrony praw człowieka; dostęp do informacji; myśle- } \\
\text { nie strategiczne; responsywność; równe traktowanie; orientacja } \\
\text { na konsensus, wydajność, efektywność; odpowiedzialność }\end{array}$ \\
\hline New Public Leadership & $\begin{array}{l}\text { Bagatelizuje sferę wartości, zaufania i współpracy; jest zorientowa- } \\
\text { na na osiaganiu wymiernych celów, rezultatów; wymaga działania } \\
\text { w środowisku sieciowym, współdziałania z wieloma grupami } \\
\text { interesariuszy; akcentuje rolę lidera }\end{array}$ \\
\hline
\end{tabular}

Źródło: opracowane własne na podstawie Polityka administracyjna i zarzadzanie publiczne, Kulesza M., Sześciło D., Wolters Kluwer Polska SA, Warszawa 2013, s. $118-120$.

PG jest modyfikacją NPM, która jest skierowana bardziej na zewnątrz administracji, co przejawia się skoncentrowaniem na socjologicznym aspekcie zarządzania publicznego i tworzeniu relacji między sektorem publicznym i prywatnym [Kulesza M., Sześciło D., 2013, s. 128-129].

PG w praktyce JST przejawia się w procesie tworzenia budżetu partycypacyjnego, który jest „umową społeczną” zawieraną między mieszkańcami a władzami samorządowymi ${ }^{6}$. Konsultacje społeczne są najczęściej prowadzone przez samorządy w przypadku uchwalania miejscowego planu zagospodarowania przestrzennego oraz opracowania programu współpracy z organizacjami pozarządowymi [Kulesza M., Sześciło D., 2013, s. 121]. Zgodnie z ideą PG, JST tworzą rady, komitety, zespoły z udziałem przed-

6 Pierwszy budżet obywatelski w Polsce wprowadzono 2011 r. w Sopocie [http://www.instytutobywatelski.pl/14426/publikacje/raporty/raport-budzetpartycypacyjny-krotka-instrukcja-obslug]. 
stawicieli organizacji pozarządowych i innych ${ }^{7}$. Coraz częściej posługują się nową technologią do komunikowania z mieszkańcami, np. informując o najważniejszych wydarzeniach za pomocą wiadomości SMS ${ }^{8}$.

\section{WNIOSKI}

Polskie JST zarządzanie są w sposób mieszany, tzn. łączący klasyczne podejście administracyjne z podejściem menedżerskim. Presja współczesności związana z niestabilnym, i nieprzewidywalnym środowiskiem, szybkim tempem rozwoju technicznego i technologicznego, globalizacją, wzrostem oczekiwań społecznych, budowaniem społeczeństwa informacyjnego wymusza konieczność wyposażenia jednostek samorządowych w adekwatne instrumenty i narzędzia działania, które są odpowiednie dla procesów governance. Mimo to zarządzanie JST nadal pozostaje pod dużym wpływem systemu politycznego oraz jego mechanizmów.

Sposób zarządzania JST decyduje o skuteczności rozwiązywania problemów i standardzie życia danej społeczności lokalnej, co wiąże się z ogromną odpowiedzialnością władz samorządowych. Celem adaptacji biznesowych metod zarządzania do administracji samorządowej było pobudzanie rozwoju aktywności gospodarczej i społecznej. Uwzględniając rozwój nowych technologii, ciągły wzrost znaczenia informacji oraz budowanie społeczeństwa informacyjnego, dalsza ewolucja zarządzania organizacjami samorządowymi będzie prawdopodobnie ucieleśnieniem koncepcji organizacji uczącej się oraz zarządzania wiedzą. Cechą charakterystyczną organizacji uczącej się jest zasobność w kreowanie, pozyskiwanie oraz transfer wiedzy, a także modyfikowanie swego zachowania na nową wiedzę i jej wartość, co z pewnością usprawni proces wykrywania i naprawiania błędów. Z kolei poszerzanie kompetencji pracowników samorządowych może przełożyć się na zwiększenie ilości różnorodnych projektów, czy działań innowacyjnych. Efektem wykorzystania nowych technologii (zarządzanie wiedzą) będzie poprawa jakości informacji, skrócenie

7 Przykładowo Rybnicka Rada Seniorów.[http://rybnik.naszemiasto.pl/tag/rada-seniorow-rybnik.html].

8 Więcej na ten temat SMS z urzędu już prawie w 600 miastach [http://www. portalsamorzadowy.pl/spoleczenstwo-informacyjne/sms-z-urzedu-juz-w-prawie-600-miastach,75091.html]. 
czasu załatwiania spraw, poprawa poziomu świadczonych usług, zwiększenie wydajność JST oraz poprawa satysfakcji mieszkańców.

W świecie współczesnego zarządzania nowa burzliwa rzeczywistość będzie wymuszać rozwój nowych kierunków zarządzania, z których część stanowić będzie chwilowe, przemijające mody. Jednakże kolejnym krokiem w ewolucji zarządzania publicznego wydaje się zastosowanie w praktyce koncepcji organizacji uczących się i zarządzania wiedzą, których zastosowanie umożliwi m.in. realizację koncepcji regionów uczących się ${ }^{9}$, co z kolei pozytywnie przełoży się na rozwój ekonomiczny danego regionu oraz poziom życia jego mieszkańców.

\section{LITERATURA}

Barber B.R., (2014), Gdyby burmistrzowie rzadzili światem. Dysfunkcyjne kraje, rozkwitające miasta, Warszawskie Wydawnictwo Literackie MUZA S.A., Warszawa.

Batko R., (2013), Golem Awatar Midas Zloty Cielec. Organizacja publiczna w plynnej nowoczesności, Wydawnictwo Akademickie SEDNO, Warszawa.

Bukowski Z., Jędrzejewski T., Rączka P., (2011), Ustrój samorządu terytorialnego, Wydawnictwo „Dom Organizatora”, Torun.

Drucker P.F., (2000), Zarzadzanie w XXI wieku, MUZA S.A., Warszawa.

Frączkiewicz-Wronka A., (2008), Zarzadzanie publiczne, światto w tunelu czy następna ściana dla sektora publicznego [w:] Zeszyty Naukowe Wałbrzyskiej Wyższej Szkoły Zarządzania i Przedsiębiorczości Nr 11 (1) 2008 Refleksje społeczne-gospodarcze [online], Wydawnictwo Wałbrzyskiej Wyższej Szkoły Zarządzania i Przedsiębiorczości w Wałbrzychu, Wałbrzych, www. pracenaukowe.wwszip.pl/prace/zeszyty-naukowe-11.pdf [05.01.2016].

9 Za Portalem Innowacji: „Koncepcja regionów uczących się zakłada, że czynniki konkurencyjności przedsiębiorstw, które umożliwiają im funkcjonowanie na rynkach światowych, jak: innowacja, elastyczność, strategie, sieci, przedsiębiorczość, itp. powstają w warunkach rozwoju lokalnego. Region uczący się jest złożony z aktorów silnie ze sobą powiązanych w struktury elastyczne zarządzane, gdzie sieć nie jest ograniczana do aktorów gospodarczych, ale włącza aktorów społecznych, politycznych i instytucjonalnych, gdzie przekazywanie i wymiana informacji nie jest zjawiskiem okazjonalnym, ale normalnym i częstym. Region, który posiada te elementy uczy się, poprawia swoje funkcjonowanie i rozwija się w sposób trwały, nawet, gdy jest on konfrontowany z nowymi, nieznanymi mu dotychczas wyzwaniami" [http://www.pi.gov. pl/parp/chapter_96055.asp?soid=B9DADAD79E474909B84B303A43A714A7]. 
Griffin R.W., (1999), Podstawy zarządzania organizacjami, Wydawnictwo Naukowe PWN, Warszawa.

Hausner J., (2008), Zarzadzanie publiczne, Wydawnictwo Naukowe SCHOLAR, Warszawa.

Kowalczyk L., (2008), Współczesne zarządzanie publiczne jako wynik procesu zmian w podejściu do administracji publicznej [w:] Zeszyty Naukowe Wałbrzyskiej Wyższej Szkoły Zarządzania i Przedsiębiorczości Nr 11 (1) 2008 Refleksje społeczno-gospodarcze [online], www.pracenaukowe.wwszip.pl/ prace/zeszyty-naukowe-11.pdf [05.01.2016].

Kożuch B., (2015), Zarządzanie publiczne jako teoria i praktyka [w:] Instrumentarium zarządzania publicznego, Kożuch B., Sułkowski Ł. (red.), Difin, Warszawa.

Kulesza M., Sześciło D., (2013), Polityka administracyjna i zarządzanie publiczne, Wolters Kluwer Polska SA, Warszawa.

Postawka M., (2001), Podstawy finansów publicznych, Wydawnictwo SGGW, Warszawa.

Supernat J., (2005), Administracja publiczna w świetle koncepcji New Public Management [online], http://www.supernat.pl/artykuly/administracja_publiczna_w_swietle_koncepcji_new_public_management.html [23-01-2016].

Ustawa z dnia 8 marca 1990 r. o samorządzie terytorialny (Dz. U. 1990 nr 16, poz. 95).

Ustawa z dnia 5 czerwca 1998 r. o samorządzie województwa (Dz. U. 1998 nr 91, poz. 576).

Ustawa z dnia 5 czerwca 1998 r. o samorządzie powiatowym (Dz. U. $1998 \mathrm{nr}$ 91, poz. 578).

Ustawa z dnia 25 czerwca 2015 r. o zmianie ustawy o samorządzie gminnym oraz niektórych innych ustaw (Dz. U. 2015 poz. 1045).

Wankiewicz B., (2009), Zasoby finansowe a rozwój samorzadności lokalnej. Obszary rozwoju - rozwiazania modelowe, CeDeWu Sp. z o.o., Warszawa.

Wojciechowski E., (2012), Zarzadzanie w samorzadzie terytorialnym, Difin, Warszawa.

Wójtowicz W. (red.), (2002), Zarys finansów publiczny i prawa finansowego, Dom Wydawniczy ABC, Warszawa.

Zawadziak T., (2014), Zarzadzanie w organizacjach sektora publicznego, Difin, Warszawa.

http://capepoint.pl/budzet_zadaniowy_w_samorzadach [25-01-2016].

http://www.instytutobywatelski.pl/14426/publikacje/raporty/raport-budzetpartycypacyjny-krotka-instrukcja-obslugi [25-01-2016]. 
http://www.pi.gov.pl/parp/chapter_96055.asp?soid=B9DADAD79E474909B84B303A43A714A7 [27-01-2016].

http://www.portalsamorzadowy.pl/prawo-i-finanse/ustawa-o-samorzadziegminnym-podpisana-przez-prezydenta,72124.html [01.01.2016].

http://www.portalsamorzadowy.pl/spoleczenstwo-informacyjne/sms-z-urzedu-juz-w-prawie-600-miastach,75091.html [25-01-2016].

http://rybnik.naszemiasto.pl/tag/rada-seniorow-rybnik.html [23-01-2016].

http://samorzad.infor.pl/temat_dnia/387395,System-zarzadzania-jakoscia-w-jedno stkach-samorzadu-terytorialnego.html [23-01-2016].

\title{
DEVELOPMENTS IN LOCAL GOVERNMENT MANAGEMENT UNIT
}

\begin{abstract}
Management is "an organized process of directing influence on the organization's resources through specific measures, forms and methods to ensure effective achievement facing the organization legally established targets" [Zawadziak, 2014, p. 52]. Over the years, changing environmental conditions, expectations of citizen, the development of technology observed the process of evolution of public management methods of the autocratic after managerialism. This paper presents the theoretical concepts of public management, which due to the narrow frame was limited to a brief overview.
\end{abstract}

Keywords: local government unit, public management 